\title{
Western Education on the Changing Roles of Women: The Case of Idakho Community, Kenya
}

\author{
Leen Kavulavu \\ Moi University, Eldoret, Kenya
}

\begin{abstract}
This study examined the contribution of Western education as provided by Christian missionaries on the changing roles of Idakho women. The spread of Christianity and Western education in Idakho had a broad approach to reinforce evangelization and to win converts. Education, thus, became part of the new value system less identified with transmitting Christian values and belief and more with providing access to new occupational and social status. The colonial authority further introduced hut taxes and cash economy. Thus, the colonial economy forced men in Idakho to seek employment in European economic ventures and took them away from the labour responsibilities they used to have in the traditional economy. With frequent absence of men, who left their villages to seek paid employment in urban areas or settler's farms, and the decline of traditional institutions and uncertainty arising from changes in society, more and more women joined the church in search of new vision of the world as well reassurance. Women who went to school initiated the beginning of a wage-earning class of women among the Idakho and it reflected the widening transformative impact of Christianity and its agencies. Methodology for this study involved data collection from secondary sources and primary data derived from field research. Moreover, the early success of education and other programs, like health, led to the liberation of women who became agents of transforming Idakho society.
\end{abstract}

Keywords: Christianity, education, Idakho, socio-economic, women

\section{Introduction}

Christianity increasingly became a religion of choice and a dominant aspect of the Idakho culture during the colonial period. Then, after the 1940s, the educated Idakho replaced the ageing pioneer converts and were able to represent the views of the church at a large and for mission and church support for education. Acceptance of Christianity also led to increased demand for education. After the 1940s, education became increasingly universal and included a growing desire for secondary schools. The end product of the rapid acceptance of Christianity and education was broader economic transformation in the post-war period. Idakho saw education as an avenue for accumulation of wealth, through employment as teachers and government employees as well as through involvement in commercial activities.

Moreover, the most notable development in Idakho was the changing status of women as reflected in the interest in girl child education, a development in which the church took the lead. Church leaders in Idakho emphasized that education for their daughters was not only an investment, but also an investment in the

Leen Kavulavu, Ph.D. candidate, Department of History, Political Science and Public Administration, School of Arts and Social Sciences, Moi University. 
family's social security. This was from the evidence found in Idakho, which indicated that a high proportion of girls who had gone to school tended to use their education to help siblings and were more concerned with contributing to siblings' school fees than boys who tended to emphasize acquiring capital to buy land (Joseph Lumwamu Muyeka, oral interview, September 19, 2012). The success of female education made more parents begin to view girl child education equally important as that of boys. This attitude clearly reflected the new contrasting roles of Christian women and men, in the new economic situation of the 1960s. Specifically, this study attempts to assess the impact of Western education on the changing roles of women with special reference to Idakho and to consider the challenges that may influence girls' education.

\section{Methodology}

\section{Objective}

The objective of this study was to identify the impact of Western education on women among the Idakho.

\section{Sample}

The study was carried out in Kakamega South District among the Idakho from August to November 2012. The key informants for the study consisted of:

1. Elders from the Idakho community. These officials were very useful in providing valuable information on the roles of women in Idakho before the coming of Christianity and the process of change that occurred among the women in Idakho when they embraced Christianity;

2. Those who work closely with the church, for instance, church administrators and church elders. They provided useful information on the role of mission churches played as agents of change in the area where they established their presences;

3. Spiritual leaders and some Christian converts who played a crucial role as agents of change as was directed by Christian missionaries. They provided information about the teachings and the impact of the church.

The total sample size was 22. During field work, the researcher used purposive sampling technique and snowball technique. In snowball technique, the researcher identified an elderly informant who knew the area for his great interest in the past of the Idakho culture who in turn directed the researcher to most of the surviving Idakho elders. To deal with the weakness of snowball approach, purposive sampling approach was used. In purposive technique, people with information on the culture of the Idakho before they embraced Christian values were interviewed. Informants who had information on the establishment and impact of Western education were also interviewed. These informants provided information on the impact of the missionaries in Idakho education.

\section{Data Collection}

Both primary and secondary sources of data were utilized in this study. The primary sources utilized in this study included oral interviews. The secondary information materials were accessed in major libraries in Kenya. The evidence arising from the above documents were analysed, interpreted, and proved useful in enriching oral sources. Primary data were derived from first-hand information through oral interviews conducted by the researcher.

\section{Oral Interview}

Semi-structured interviews were used to maximize discussion. The researcher verbally used questionnaires to elicit information from the interviewees by posing the questions. This was because most of them were old 
and could not read or write in English. Besides note-taking, the interviews were recorded on voice recorder and later translated into the English language, giving a verbalism account of the conversation with the informants. The questions were easily reframed to encourage free discussions other than just eliciting questions and answers. Oral interviews provided an opportunity for cross-checking of the informants to avoid possible misinterpretation and to ensure the understanding of the collected data, and hence, validity. The method allowed the researcher to understand and capture the informants' oral interviews.

\section{Data Analysis}

In analyzing the data, the study utilized qualitative data to describe in depth what was on the ground. Oral data collected from the questionnaire were compared and contrasted. Once, the oral data were organized, the researcher cross-checked the information with documentary sources. Through description, comparison, and interpretation as methods of analytical discussion, conclusions from data were made in respective stages.

\section{Results and Discussion}

\section{Pre-colonial Period}

The Idakho are a Luhyia sub-ethnic group that reside in Kakamega South District within Kakamega County (Republic of Kenya, 2009, p. 1). The Idakho occupy the area between the Maragoli and Isukha (Ngang'a, 2006, p. 34). Among the Idakho, the individual family constituted the basic social group that co-operated most widely and intensely in their activities of everyday life. It consisted of a husband, wife, and unmarried children. There was a clearly defined division of duties within the family. Both men and women played a significant role. However, this was only possible if one was married. The woman was partly the co-owner of the land that belonged to her husband. This gave women power over the home. Although this was a patriarchal society where men inherited land from their fathers, thus, accorded them a superior status. Men, for instance, would go and clear virgin land and break the earth and help women plant crops while women would weed crops. In essence, the duties carried out by men complemented those done out by women. Men and women needed one another's labour for social production. Table 1 graphically represents some of the gendered responsibilities on both sexes.

Table 1

Division of Duties Within the Family Group in Idakho

\begin{tabular}{|l|l|}
\hline Duties for men & Duties for women \\
\hline Hunting and providing security to the family; & Taking care of the home; \\
\hline Clearing the forest; & Second digging of the land; \\
\hline Breaking the ground; & Weeding; \\
\hline Offering sacrifices on behalf of the family; & Singing on public occasions; \\
\hline In charge of the security; & In charge of the domestic chores; \\
\hline Negotiating dowry; & Asking for brides; \\
\hline Socialising boys and taking boys for circumcision; & Socialising daughters; \\
\hline Taking cattle, goats, and sheep to the grazing field; & Gathering firewood; \\
\hline Serving chicken; & Serving food except chicken; \\
\hline Slaughtering an animal. & Cooking and entertaining female guests. \\
\hline
\end{tabular}

Note. Source: Primary research. 
The outlined gendered division of labour was reinforced by a set of taboos that governed the family unit.

The old men were usually useful in oral traditions, narrating stories or secrets to the young men. It was also their duty to settle difficult cases especially those involving land ownership and traditional customs. The old women were useful in a similar manner, but they were usually concerned with advising women and girls. It is worth noting that most of the informants acknowledged the fact that the worst curse that one could ever receive came from a woman. This involved a woman, mostly elderly, stripping naked. This act was followed by utterances of condemnation from the women. It was therefore every man's desire never to push a woman to that level, be it one's wife or relative. Taboo, therefore, seemed to have existed almost like a constitution among the Idakho. The following are some of the gender-inflicted taboos among the Idakho: for a man to spend time sitting in the kitchen, for a man to ridicule an old person, for a married man to sweep his own house, for a woman to sit on her husband's stool, for a woman to dig a grave, for a woman to serve chicken from 'the mans' pot", for a woman to eat chicken or eggs, for a daughter-in-law to take milk to one's father-in-law's house, for a newly wedded wife to drink sour milk before bearing a child, for a woman to milk cows, and for a woman to visit a witch doctor. These taboos governed the way of life of the Idakho.

Children were trained at an early age to share the duties of family life. At about the age of six, boys began to herd sheep, goat, and cattle, a duty which they outgrew after being circumcised. The girls assisted their mothers in the daily work of fetching water, gathering firewood, wild roots, and vegetables, and above all, in the weary task of grinding finger millet. Polygamy was a common practice among the Idakho during the pre-colonial period. To some extent, it was perceived as having to do with giving security to the man. Another reason advanced in support of polygamy was that a man's wealth was measured in terms of the number of wives, children, or livestock he had (John Beti, oral interview, September 20, 2012). A man who had wealth was respected. It was therefore prestigious to have many wives among the Idakho during the pre-colonial period. Wife inheritance was one of the cherished institutions among the Idakho. A woman once married belonged to the clan. The death of the husband in some sense loosened the ties that bound the woman to the clan. A clan member or an age made to the deceased husband was asked to inherit the woman. Thereafter, elaborate rituals were performed (Enock Shivachi, oral interview, November 12, 2012).

\section{Western Education in Idakho During the Colonial Period}

Literacy introduced the Idakho to a new "world" and a different sense of self. Literacy meant a paying job, better social status, and authority over those who could not write. Pupils were also engaged in a variety of training, which gave them manual skills. Such training included brick-making, building modern and improved houses, hygiene, and improved crop production (Meshack Anjioni, oral interview, September 17, 2012). It was through such industrial training that the missionaries intended to introduce more than just the Bible to the Idakho. The missionaries also made a major contribution to Idakho education by insisting that boys and girls should have equal access to education. According to the Idakho culture, women and children were considered as "objects and not subjects". For instance, most of the Idakho traditions stated that "Women and children shall be given care and protection". Consequently, when the male head was not at home, his wife would say "There is no one here except me and the children" (Noel Nabwangu, oral interview, September 17, 2012). This traditional view is what was opposed by the missionaries. When they instituted education for women, missionaries thus viewed women as "subjects". Accordingly, women were now supposed to be given access to more privileges previously denied to them, for example, the right to eat chicken and eggs. 
Christianity thus met:

Resistance on the part of Idakho elders difficult to overcome, particularly regarding girl child education. Idakho men believed that women were to perform domestic duties and not "waste" time in class. Missionaries, however, encouraged girls to go to schools where reading and writing, elementary arithmetic, cooking, knitting, laundry, and child-care were taught. However, changing the community's perception towards girl education was not that easy. This was largely due to the fear that educated women might "question the privilege of elders to select husbands for them". (Odwako, 1975, pp. 60-62)

Initially, women seeking education were those who had convinced their fathers that education was necessary for a girl child or who had run away from home in order to pursue education at missionary centre. But after the 1930s, fathers who had converted to Christianity and received missionaries training began to push for the education of their daughters and sent them to school (Elkana Muhalia, oral interview, September 20, 2012). Marginalized members of the society, e.g., witches and women escaping from forced marriage, converted to Christianity with the aim of gaining a new identity. To these people, therefore, conversion constituted a therapeutic act of self-aggrandizement.

Women of Idakho who went to school were taught rudimentary methods of maternal and child care, nutrition, and home-making. One of the women teacher evangelists was Gladys Etemere, who became a primary teacher at Bushiangala School in Idakho. In addition, women who went to school initiated the beginning of a wage-earning class of women among the Idakho, and it reflected the widening transformative impact of Christianity and its agencies. With the success of the pioneer working class women, parents began to take their daughters to schools in increasing numbers outside Idakho area, mainly to Bunyore Girls in Kima, Girls Boarding School (GBS) at Kaimosi, and Butere Girls. Subsequently, girl child education, just like that of boys, was seen as a future investment. Parents, therefore, were willing to pay school fees for their daughters (Gladys Thomas Shihami, oral interview, September 17, 2012).

\section{Social Transformation}

In the period between 1950s and 1963, the most notable development in Idakho was the changing status of women, as reflected in the interest in girl child education. The Idakho emphasized that education for their daughters was not only an investment, but also an investment in the family's social security. This was from the evidence found, which indicated that a high proportion of girls who had gone to school tended to use their education to help siblings and were more concerned with contributing to siblings' school fees than boys who tended to emphasize acquiring capital to buy land (Joseph Lumwamu Muyeka, oral interview, September 19, 2012). The success of these female education made more parents begin to view girl child education equally important as that of boys. Indeed, educated women attracted a higher bride price. This was because like men, educated women were employed in various sectors where they earned salaries and attained the status of the elite in their own right. This attitude clearly reflected the new contrasting roles of Christian women and men in the new economic situation of the 1960s. However, the development of girls' schools was never established in Idakho. Many Idakho girls who passed the intermediate examination were forced to find secondary education either at Bunyore Girls and other mission schools, like Butere Girls' Secondary School, Kaimosi Girls Boarding School at Kaimosi, or African Girls High School, Kikuyu. A few joined either teacher training or nursing colleges, which were then ranked lower than secondary education (Philip Nabwangu, oral interview, September 17, 2012). 
The educated elites played an important role in bringing about the process of change in Idakho. For the educated elites, the church had provided a vehicle for economic development. Church membership, therefore, not only provided the elites and their children access to higher education, but also practical experience in administrative procedures and behaviour according to new social norms. These were important skills for holding responsible positions in local government. In many locations in Idakho, administrative officers were men who had attended schools (Gladys Thomas Shihami, oral interview, September 17, 2012).

As these new economic patterns developed, women and children increasingly dominated church membership among the Idakho converts. Yet, the male educated elites still controlled the most influential positions in the churches and directed its attention to the needs of the educated. For instance, although there were qualified women teachers in the 1960s, none of them was a headteacher. Although women could preach or lead prayers and hymns in the churches at the local level, they rarely sat on the important finance or nominating committees. One major limit to the power of women though was the dissent especially in their views about women exercising leadership over men. In this conflict, the church did little to serve the needs of women whose roles were seen by the African leadership as one of performing a supportive role in the church development (Lawi Masinjira, oral interview, September 21, 2012).

In one way or another, missionaries were great innovators in Idakho society. Becoming a Christian brought considerable material advantages; "progressive" sector with paid jobs, such as teachers and the pursuit of wealth or wider knowledge. The gradual shifting from economic self-sufficiency within the family to increasing dependence on outside markets and a money income from wage labour affected both division of labour and social cohesion of the family. With regard to division of labour, where increasing demand for a cash income was met by a more intense cultivation of the soil for the production of commercial crops, the female members of the household often had to bear the brunt of extra work while men were out on wage labour.

The economic part played by the wife in the household economy became quite different from that in the traditional family. She was no longer tied down to so many daily duties of the family, provided her husband was wealthy enough to afford hired labour. Women gained a new freedom. They were relieved to most of field work and hence devoted more time to bringing up their children and to a more elaborate housekeeping, with the demand for a higher material standard of living (Wagner, 1939, p. 39). In many ways, this weakened the economic case of polygamy. At the same time, many young men were accustomed to looking after themselves through the life of urban towns or as wage labourers on Europeans plantation led to a bachelor life and postponed marriage until the late 1920s. Moreover, widowers, who formerly were forced for economic reason to remarry, often stayed single.

Apart from Christianity, the establishment of colonial rule in Kenya provided some insights to some women in Idakho who came to know their rights within the new social environment. During the pre-colonial era, women were totally submissive to their husbands. But with the establishment of colonial rule, new social and economic development occurred which drastically changed the position of women in Idakho. Missionaries preached against some cultural practices, such as polygamy and other related anti-Christian practices (Wagner, 1939, p. 39). Women converts therefore demanded that they should not be bound by such customs that were contrary to Christianity. At the same time, women were able to generate their own cash income as wage labourers and some became teachers, matrons, and evangelists in the area. All these opportunities allowed women to acquire some degree of independence. 


\section{Socio-economic Challenges Facing Women in Idakho After Independence}

Since independence, the government of Kenya has always started clearly the role of the state in fostering the country's socio-economic development. Specifically, over the years, the government spelt out the role of the state to fight against ignorance, disease, and poverty. This was to be achieved through the provision of education to all Kenyans in regardless of ethnicity and gender; providing health services to all citizen through subsidized services; developing the agricultural sector, the mainstay of the country's economy; investing in the industrial sector; and creating employment opportunities in the public and informal sectors. Although roughly equal numbers of girls and boys in Idakho enrolled in the first year of primary education, fewer girls than boys proceed to secondary and higher education levels. Girls are pushed out of school mainly due to social, economic, and cultural factors. For instance, poverty is a worrisome problem facing most Idakho families. Whenever parents are unable to raise school fees for their children, girls are always forced to drop out of school.

The small and informal sector, be it "jua Kali" (as popularly known in Kenya), farmers or small-size entrepreneurs have problems of access to credit. Besides, there is a weak protection of property rights for the poor (especially poor women) and it is difficult to obtain lease to operate businesses both in the rural and urban areas. The condition for commercial credit from banks and financial institutions (for example, Agricultural Finance Corporation) is particularly difficult for women in Idakho. The requirements of operating an account in a bank which goes together with wage employment and/or having other source of income, providing security in the form of land or a house, and having to pay high interest rates, can only be met by a select group of borrowers and a few indeed women in Idakho.

As noted by Nangulu (2009, pp. 107-111), the infrastructure and the business environment are also biased against the poor, with frequent electricity cuts, due to over dependency on the hydro-electric power as the main source of energy, that also relies on rainfall, which at times is sporadic, back up services lie the use of generators are needed, although they are costly beyond the reach of the poor in Idakho. Moreover, all whether roads do not reach various parts of the Idakho area, where the majority of the poor and the population in general reside, thus, costs of transport become barriers to entry into business or expansion for these groups of people. Licence, justice, and regulation, all needed for economic growth, are often too costly to obtain for those in the small and informal sector. Thus, low level of education coupled with retrogressive socio-cultural practices have resulted in women's low participation and representation in decision-making position. Consequently, they lack full access to adequate economic opportunities and resources. Nonetheless, a considerable number of women in Idakho operate in informal businesses. They are mainly engaged in a range of activities which include market trade, hairdressing, sewing, knitting, home craft, hawking of foodstuff, etc.. While the majority of these enterprises remain small and do not bring major financial success to their founders, they have enabled them to be self-employed and to make substantial contribution to their families.

\section{Conclusion}

This study has shown that Christianity had expressed the desire to improve the lives of women and their families through education and had recognized that without female education, progress would be hindered. Church leaders strongly supported increasing the responsibility of women in church affairs and also encouraged greater equality between husbands and wives, insisting that domestic decisions be made jointly, or even that certain decisions be delegated to the wives. Despite such progressive ideology, women's leadership roles did 
not increase to any greater extent in the church and schools. Missionary education however set forth as a means of not only gaining adherents, but also of changing the society. As education produced the first modern elite women among the Idakho, many families began to see the advantages of education in the colonial situation and consequently sent their children to school. Education is development; it can make a lot of difference in the development in any society. Therefore, a lot of resources, human, and otherwise are being expanded globally to deal with the problem of gender inequality. This can be explained by the fact that governments have faith in education as an investment (Nangulu, 2009) to benefit all members of the society regardless of gender. Furthermore, through education, students from both poor and rich families can develop the necessary skills to become productive citizens and participate more efficiently in national development.

\section{References}

Nangulu, A. (2009). The state and challenges of the socio economic development in Kenya. Maarifa Journal of Humanities and Social Sciences, 3(2), 106-111.

Ngang'a, W. (2006). Kenya's ethnic communities foundation of the nation. Nairobi: Gatundu Publisher Limited.

Odwako, E. H. (1975). The church and education: The contribution of church missionary society to education in Western Kenya, 1905-1963 (M.A. thesis., University of Nairobi).

Republic of Kenya. (2009). Kakamega South District development plan 2008-2012. Nairobi: Government Printer.

Wagner, G. (1939). The changing family among the Bantu Kavirondo. London, U.K.: Oxford University Press. 